\title{
Age, Growth and Ovarian Histology of Sardinella aurita (Valenciennes, 1847) in the South of Atlantic Moroccan Coast
}

\author{
Ayoub Baali ${ }^{1, *}\left(\mathbb{D}\right.$, Oum Keltoum Belhsen ${ }^{1}$, Khalil Chahdi ouazzani ${ }^{2}$, Khadija \\ Amenzoui ${ }^{1}$, Ahmed Yahyaoui ${ }^{2}$ \\ ${ }^{1}$ Institut National de Recherche Halieutique, Fishery Department, Casablanca, Morocco. \\ ${ }^{2}$ Mohammed V University, Biodiversity, Faculty of Science, Ecology and Genome Laboratory, Rabat, Morocco.
}

\section{How to cite}

Baali, A., Belhsen, O., Chahdi ouazzani, K., Amenzoui, K., Yahyaoui, A. (2021). Age, Growth and Ovarian Histology of Sardinella aurita (Valenciennes, 1847) in the South of Atlantic Moroccan Coast. Turkish Journal of Fisheries and Aquatic Sciences, 21, $191-204$. http://doi.org/10.4194/1303-2712-v21_4_04

\section{Article History}

Received 06 June 2020

Accepted 25 Jaunary 2021

First Online 26 January 2021

Corresponding Author

Tel.: +212623755804

E-mail: ayoubbaali22@gmail.com

\section{Keywords}

Round sardinella

Atlantic coast

Otoliths

Stock assessment

\begin{abstract}
Otoliths reading and length frequency distribution were used for age determination and growth estimation of Sardinella aurita (round sardinella) stock of Southern Atlantic coast of Morocco. Both otoliths' method for age determination and Bhattacharya's method for length frequency analysis showed five age groups. The growth performance index revealed that there is significant accordance among method of length frequency distribution and otoliths reading for stock assessment studies of Sardinella aurita stock in the south of Morocco. The microscopic observation of female gonads using histology method was investigated for the first time in our study area and confirms the presence of five principal stages of ovary of sardinella aurita: immature, maturing virgin and recovering spent, mature (or pre-spawning phase), spawning, post-spawning or spent. In addition, our results of the fecundity showed that the mean relative fecundity obtained is estimated at $193 \pm 98$ oocytes/g which is lower compared to those obtained in other areas in the Atlantic coast.
\end{abstract}

\section{Introduction}

Round sardinella, Sardinella aurita Valenciennes, 1847 (Pisces, Clupeidae), is a widely distributed, middlesized pelagic fish. The distribution of the species is tropical and subtropical often associated with major upwelling systems and sea surface temperature (Durand et al., 1998; Baali et al., 2019). The intermediate position that $S$. aurita occupy in the food web gives them a particular importance compared to other species. In the North West Africa, this species is part of stocks that are not restricted to the territorial waters of a single country, but extend into the territorial waters of two or more neighboring riparian countries (shared stocks). Moreover, some stocks are migrating along the coast: they could be in the exclusive economic zone (EEZ) of a country for part of the year and in other EEZ(s) for the rest of the year. Hence, $S$. aurita is a key species among the ecosystem of the northwest African upwelling region (Bard and Koranteng, 1995). Although Sardinella aurita is still one of the most pelagic species caught in the south of Morocco, its biomass has known fluctuations these last years (Baali et al., 2017). The study of reproduction and growth of the round sardinella has been thoroughly studied in the Mediterranean Sea (Wassef et al., 1985; Bensahla Talet et al., 1988; Stergiou et al., 1997; Bouaziz et al., 2001; Gaamour et al., 2001; Dahel et al., 2016) and the Atlantic Ocean (Fontana, 1969; Pham-Thuoc and Szypula, 1973; Cury and Fontana, 1988; Roy et al., 1989; Bakun and Parrish, 1990; Fréon et al., 1997; Quaatey and Maravelias, 1999; Samba, 2011; Baali et al., 2015, 2017). However, little is known about the growth of Sardinella aurita and no study has been done about its fecundity and ovarian histology in our study area. In the present investigation, data on the age and growth of $S$. aurita for the southern Moroccan coast are evaluated. In addition, we are going to estimate the Sardinella aurita fecundity 
for the first time in the south of Moroccan coast as well the microscopic stages of the female gonad using ovarian histological sections. The knowledge of spawning stages and spawning frequency based on growth parameter is important for determining potential annual fecundity as a function of fish size and understanding the dynamic of this species, thus providing appropriate statistical models for rational exploitation (Farley et al., 2015; Baali et al., 2017).

\section{Materials and Methods}

\section{Sampling}

The study was conducted upon 838 specimens of Sardinella aurita collected monthly from February 2015 to January 2017 throughout the South of Moroccan Atlantic coast in the area between Cape Boujdor and Cape Blanc from commercial fishermen, who generally use purse seine as fishing gear. Sampling frequency depends on the abundance of sardinella because it is not always available in our fishing areas. In the laboratory, the caught fishes are sorted, identified, inventoried and weighted. The total length (TL) and the total weight (TW) of the fish sampled were measured to the nearest 0.1 $\mathrm{cm}$ and $0.1 \mathrm{~g}$ respectively. Gonads were removed from each individual to identify the sex and then weighted (GW) at the nearest $0.01 \mathrm{~g}$.

\section{Growth Study}

The length-weight relationship (LWR) was estimated according to Froese (2006) power equation:

$$
W=a \times T L^{b}
$$

Where $\mathrm{W}$ is the weight (g), TL is the total length (cm), a (intercept) and b (slope). These last two parameters were estimated by regression curve analyses based on the logarithmic transformed equation (Beverton and Holt, 1957):

$$
\log 10 W=b \times \log 10 T L+\log 10 a
$$

The Pearson's correlation $\left(r^{2}\right)$ and the growth exponent (b) were used respectively as an indicator of significance of regression and to determine the type of growth (isometric if $b=3$, allometric if $b \neq 3$ ). The test used for checking the isometry $(b=3)$ or allometry $(b \neq 3)$ of length-weight relationships is the $t$ test of student after linearization of the relationship by logarithmic transformation (Pajuelo and Lorenzo 2000; Arneri et al. 2001).

This test consists of comparing the slope of the regression line (b) with a theoretical slope equal to 3 . The main hypothesis proposes that there is no significant difference between the slope (b) and the value 3 . The alternative hypothesis assumes that there is a significant difference between the slope (b) and the value 3 .
So:

If $\mathrm{t}_{\mathrm{obs}}<\mathrm{t}_{0.05}, \mathrm{n}$, the main hypothesis is accepted; and if $\mathrm{t}_{\text {obs }}>\mathrm{t}_{0.05}, \mathrm{n}$, the main hypothesis is rejected.

Otoliths were removed from each specimen. We chose the sagittae which have a large size allowing a better readability of the marks. Their extraction was done using a fine tweezer after a transverse head section, inclined at $45^{\circ}$ between the eyes and the operculum. The age of Sardinella aurita was estimated using two methods: otoliths and Bhattacharya's methods. In the first one (direct method using otoliths); annual rings on otoliths were counted using optical system consisting of Nikon Zoom - Stereomicroscope. From these counts, the age classes were assigned with additional sets of the time of the formation of growth marks and the month the fish were sampled. The date of birth for $S$. aurita were set at April, which approximately corresponds to the peak spawning period based on information on maturity stages and gonadosomatic index occurred in our study area (Baali et al., 2017). On other note, the Bhattacharya method (1967), which is based on length frequency, was also used as second method to estimate length-at-age key through FiSAT II program (version 1.2.2) (Gayanilo et al., 1995). Thereafter, in order to estimate growth parameters $K$ and $L_{\infty}$, FiSAT II (version 1.2.2) (Gayanilo et al., 1995) program was run using Analysis of length-atage data that calculated from the two methods cited previously. This is a subroutine in FiSAT II to estimate growth parameters $K$ and $L_{\infty}$. This subroutine allows non-linear estimation of growth parameters from length-at-age data. The Von Bertalanffy plot is used to estimate to from the known age/length data and estimated $L_{\infty}$ and $K$, the method is based on the regression analysis of the following formula: - In (1-Lt / $\left.L_{\infty}\right)=-K * t_{0}+K * t$ Where: the age $t$ is the independent variable $(x)$ and $\left(-\ln \left(1-L(t) / L_{\infty}\right)\right)$ is the dependent variable (y) of the linear regression (El-haweet et al., 2005). The Growth performance $\left(\varnothing^{\prime}\right)$ was estimated using the empirical equation of (Pauly and Munro, 1984): $\left(\varnothing^{\prime}\right)=2 \log 10 L_{\infty}+\log 10 k$ (Munro and Pauly, 1983) where: $k$ and $L_{\infty}$ are the Von Bertalanffy's growth parameters.

\section{Histology and Fecundity}

After removing ovarian tissue from the body cavity of round sardinella, a maturity stages were attributed to each fish using the macroscopic maturity scale adopted by Holden and Raitt (1974) (Table 1).

Histological study was conducted on the ovarian tissue to establish the microscopic characteristics of each defined macroscopic stage and to highlight the successive stages of vitellogenesis in oocytes. A fraction of the middle part of the ovarian tissue representing different macroscopic maturity stages was sampled and fixed in Bouin solution for two to three days depending on the size and density of the sample. Tissue dehydration with a graduated ethanol solution of 
Table 1. Maturity scale for "partial spawners” (Holden and Raitt, 1974).

\begin{tabular}{|c|c|c|}
\hline Stages of maturity & State & Features ovarian \\
\hline Stage I & Immature & $\begin{array}{l}\text { Ovary and testis about } 1 / 3 \text { rd length of body cavity. Ovaries pinkish, } \\
\text { translucent; testis whitish. Ova not visible to naked eye. }\end{array}$ \\
\hline Stage II & $\begin{array}{l}\text { Maturing virgin and } \\
\text { recovering spent }\end{array}$ & $\begin{array}{c}\text { Ovary and testis about } 1 / 2 \text { length of body cavity. Ovary pinkish, } \\
\text { translucent; testis whitish, more or less symmetrical. Ova not visible to } \\
\text { naked eye. }\end{array}$ \\
\hline Stage III & Mature/pre-spawning phase & $\begin{array}{c}\text { Ovary and testis about } 2 / 3 \text { rds length of body cavity. Ovary pinkish } \\
\text { yellow colour with granular appearance, testis whitish to creamy. No } \\
\text { transparent or translucent ova visible. }\end{array}$ \\
\hline Stage IV & Ripe/spawning phase & $\begin{array}{l}\text { Ovary and testis from } 2 / 3 \text { rds to full length of body cavity. Ovary } \\
\text { orange-pink in colour with conspicuous superficial blood vessels. Large } \\
\text { transparent, ripe ova visible. Testis whitish-creamy, soft. }\end{array}$ \\
\hline Stage V & Spent/ post-spawning phase & $\begin{array}{l}\text { Ovary and testis shrunken to about } 1 / 2 \text { length of body cavity. Walls } \\
\text { loose. Ovary may contain remnants of disintegrating opaque and ripe } \\
\text { ova, darkened or translucent. Testis bloodshot and flabby }\end{array}$ \\
\hline
\end{tabular}

increasing concentrations ranging from $70 \%$ to $100 \%$, xylene clarification and paraffin infiltration were performed by an automated tissue processor (Leica ASP300). The paraffin-coated tissues were cut with a rotating microtome (Leica RM2255) to obtain $2 \mu \mathrm{m}$ thick tissue sections. After mounting on glass slides, the sections were dried in an oven for $12 \mathrm{~h}$ at $60^{\circ} \mathrm{C}$ and stained with Harris's hematoxylin and eosin (H\&E) (Martoja, 1967) using Sakura Tissue-Tek DRS 2000 Slide Stainer. The histological descriptions were achieved with a light microscope OLYMPUS BX 53 equipped with a camera at magnifications ranging from $40 x$ to $400 x$.

The fecundity study was conducted on samples of ovaries in stage IV (spawning phase) that were kept in Gilson's liquid (Simpson, 1951) for one month. Then, the oocytes are freed and can be counted under a binocular magnifying glass after removal of the remaining ovarian tissue and rinsing. Absolute fecundity (FA) was assessed by gravimetric method (Bagenal and Braum, 1978). The relationship between $F A$, length and weight of fish was described using the exponential equation: $F A=a x^{b}$, which after a logarithmic transformation takes the form $\log F A=\log a+b(\log x)$, where $x$ is either length or weight and $\mathrm{a}, \mathrm{b}$ are the regression constants. In this study, Relative fecundity (FR) was considered as the number of eggs per unit of body weight (Nikolskii, 1963). The round sardinella is a multiple spawner that lays several eggs during the same breeding season (Mustać and Sinovčić, 2012; Baali et al., 2017). The development of the oocytes occurs asynchronously, that is not all the eggs reach maturity simultaneously. Oocytes of different stages and sizes are found throughout the reproductive period. In the present study we used mature oocytes varying in size between 0.3 and $0.8 \mathrm{~mm}$ (mean $0.54 \pm 0.13 \mathrm{~mm}$ ).

\section{Results}

\section{Growth Study}

\section{Length-Weight Relationship}

The analysis of total catch data of S. aurita in the southern Moroccan coast shows that the TL ranged from
$12 \mathrm{~cm}$ to $35.5 \mathrm{~cm}$ and the TW varied between $13.12 \mathrm{~g}$ and $508 \mathrm{~g}$. The exponential expression $b$, of the lengthweight relationship was 3.27 for sexes combined that suggests a positive allometric growth and the equation would be $\mathrm{W}=0.004 \mathrm{TL}^{3.27}\left(\mathrm{R}^{2}=0.98\right)$ (Figure 1).

\section{Estimation of Age and Growth Parameters}

Using the Bhattacharya (1967) method, the population of $S$. aurita in the south of Morocco is composed of five groups with mean lengths of 14.68 , $18.07,26.55,29.26$ and $32.20 \mathrm{~cm}$ respectively (Figure 2 ).

The results of the analysis of length-at-age data (subroutine in FiSAT II software) of S. aurita allowed us to estimate: $L_{\infty}=36.24 \mathrm{~cm}$ (Figure 3 ), $K=0.42$ year $^{-1}$ and $t_{0}=-0.38$ year, hence, the linear growth model for the LT estimation according to Von Bertalanffy's would be $\mathrm{LT}=36.24\left(1-\mathrm{e}^{-0.42(\mathrm{t}-0.38)}\right)$. Therefore, the growth performance index of $\varnothing^{\prime}$ was 2.74 .

The results of length-at-age data (Table 2) carried out with otoliths reading method (Figure 4) show that Sardinella aurita attain a maximum age of about five years old with predominance of class 3 years old in the samples whereas class 0 -year-old was the less catched classes (Table 2 ). The asymptotic length $\left(L_{\infty}\right)$, the growth coefficient $(\mathrm{K})$ and the theoretical age at length $0\left(\mathrm{t}_{0}\right)$ were $34.74 \mathrm{~cm}, 0.42$ year $^{-1}$ and -1.03 year respectively. These results allowed us to determine the equation: $\mathrm{LT}=34.74\left(1-\mathrm{e}^{-0.42(\mathrm{t}-1.03)}\right)$ with growth performance index of $\varnothing^{\prime}=2.70$.

\section{Ovarian Histology}

The histological analysis of ovaries was made with reference to the size of the oocytes, the cytoplasmic homogeneity, the amount and the distribution of lipid and protein inclusions (yolk globules), and it showed five stages. Immature phases (stage I and II), mature or pre-spawning phase (stage III), ripe/spawning phase (stage IV), post-spawning phase (stage V).

Immature stage: Only oocytes in primary growth stages are present namely: oogonia $(\varnothing<10 \mu \mathrm{m})$, nuclear chromatin oocytes $(10<\varnothing<50 \mu \mathrm{m})$, early and late perinucleolar oocytes $(50<\varnothing<100 \mu \mathrm{m})$ (Figure $5 \mathrm{a})$. Nests 
of oogonia were attached to the surface of ovarian lamellae; they were characterized by small cytoplasm and an intensely basophilic rounded central nucleolus (Figure 5b). Nuclear chromatin oocytes had ring of chromatin surrounding the nucleolus and threadlike nuclear chromatin. Like oogonia, they had a small cytoplasm but were more basophilic, irregularly shaped and had a larger nucleus (Figure 5c). The early perinucleolar oocytes were larger, rounded in shape and characterized by cytoplasm and nucleoli of different sizes, both strongly basophilic (Figure $5 \mathrm{~d}$ ). In the late perinucleolar stage oocytes, the cytoplasm became less basophilic with a granular structure and multiple nucleoli that are usually peripheral. Moreover, the cytoplasm of oocytes in advanced stage differentiates into a clear outer layer and a denser inner layer (Figure 5e).

Pre-spawning stage: During this stage, primary growth oocytes are still present in the ovarian follicles concomitantly with early and late developing oocytes. The diameter of early developing oocytes ranged from
100 to $250 \mu \mathrm{m}$. They had a large, spherical, and central nucleus that contains at least one small nucleolus (Figure 6a). They are mainly characterized by the appearance of cortical yolk globules along the peripheral region of the homogeneous cytoplasm (Figure 6a) and also by a thin acellular membrane of eosinophilic material, the zona radiata surrounding these oocytes. In the late developing oocytes, the size increased reaching 250 to $350 \mu \mathrm{m}$ in diameter with the progressive accumulation of small vesicles around the nucleus that merge into larger vesicles. The yolk globules and vesicles invaded gradually the cytoplasm and gave an irregular appearance to the nuclear membrane. Simultaneously, the thickness of zona radiata increase and the follicular envelope became visible (Figure $6 \mathrm{~b}$ ). In both types of oocytes, fine chromatic granules are dispersed in the nucleoplasm. Ripe/Spawning stage: At this stage, the early stages of oocytes can be observed in the ovarian stroma with oocytes in advanced vitellogenesis which reached a size of between 350 and $450 \mu \mathrm{m}$. However, oocytes in

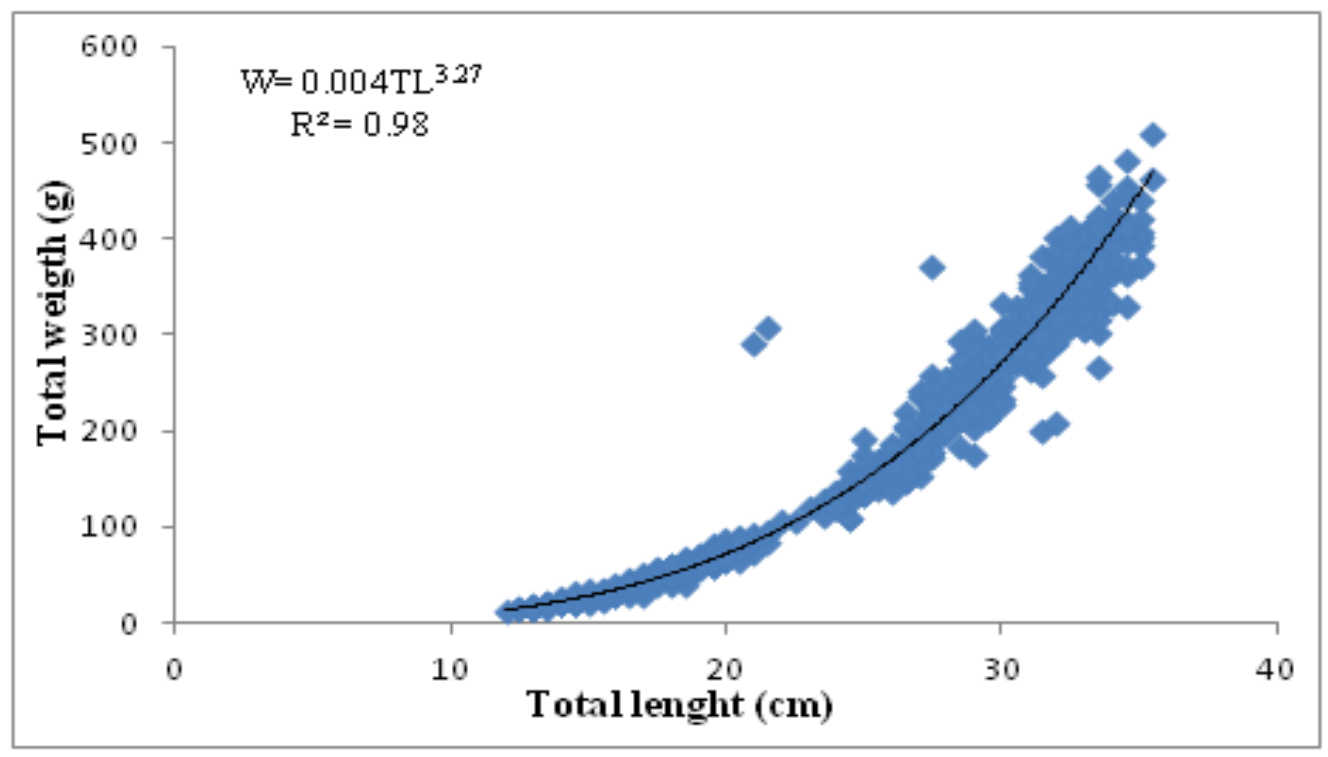

Figure 1. Length-weight relationship of S. aurita from the south of Moroccan Atlantic coast.

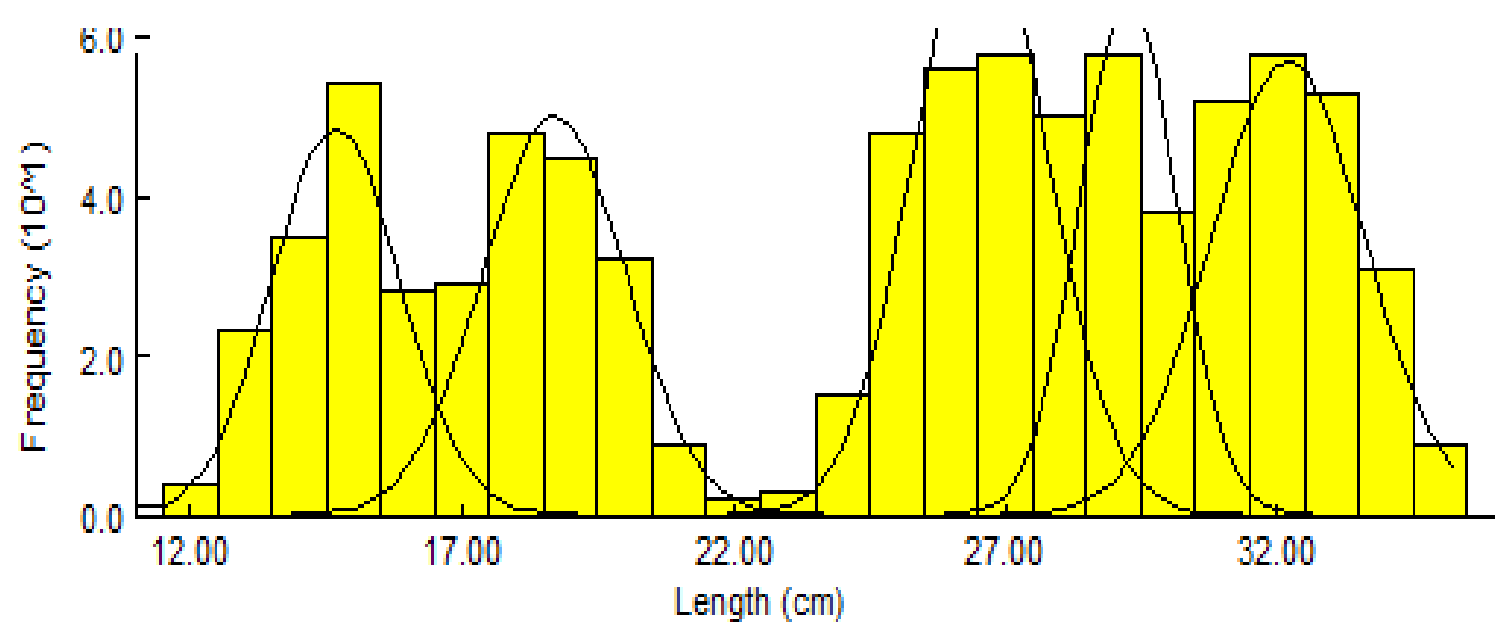

Figure 2. Length distribution of $S$. aurita separated by Bhattacharya method from the Atlantic Moroccan coast (FISAT II 1.2.2). 


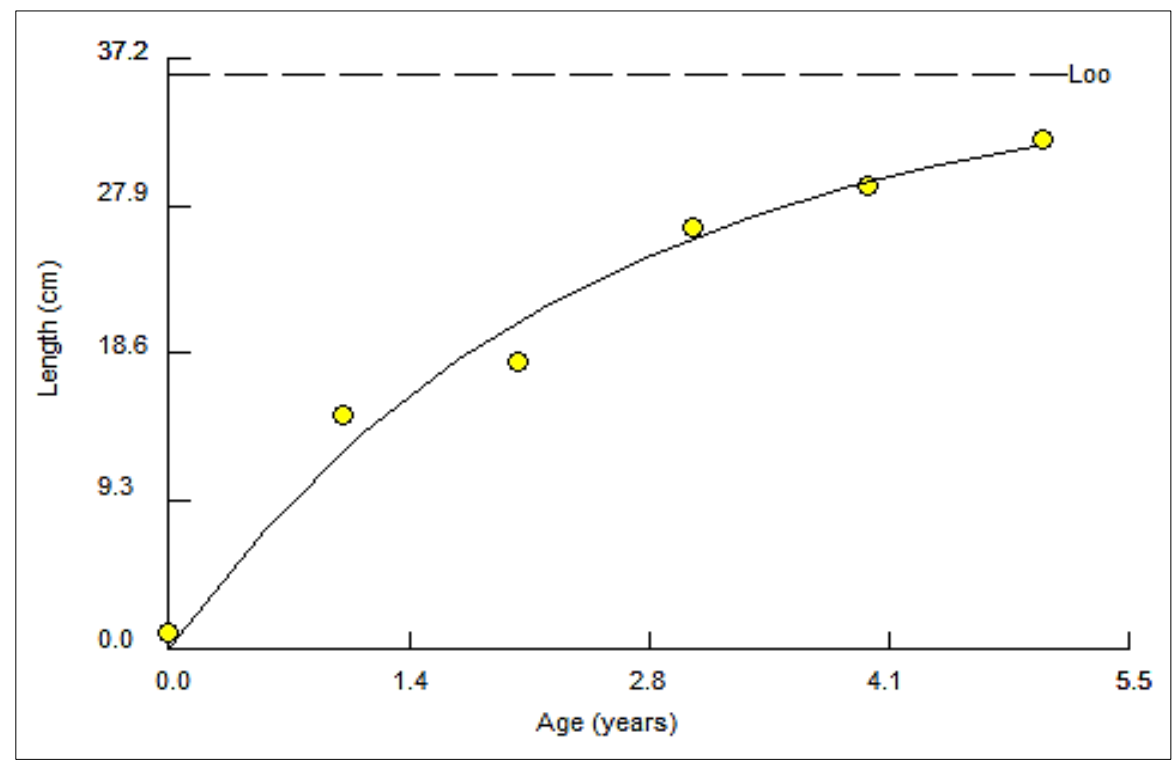

Figure 3. Asymptotic lengths $L_{\infty}$ of $S$. aurita from the Atlantic Moroccan coast (FISAT II 1.2.2).

Table 2. Age-length key of $S$. aurita sampled in the south of Atlantic Moroccan coast.

\begin{tabular}{lcccccc}
\hline Age group (year) & 0 & 1 & 2 & 3 & 4 & 5 \\
\hline Frequency & 4 & 153 & 102 & 233 & 89 & 27 \\
$\begin{array}{l}\text { Mean TL (cm) } \\
\text { (otoliths' method) }\end{array}$ & 14.62 & 18.05 & 23.87 & 28.86 & 30.72 & 32 \\
$\begin{array}{l}\text { Mean TL (cm) } \\
\text { (length frequency } \\
\text { method) }\end{array}$ & & 14.68 & 18.07 & 26.55 & 29.26 & 32.20 \\
\hline
\end{tabular}

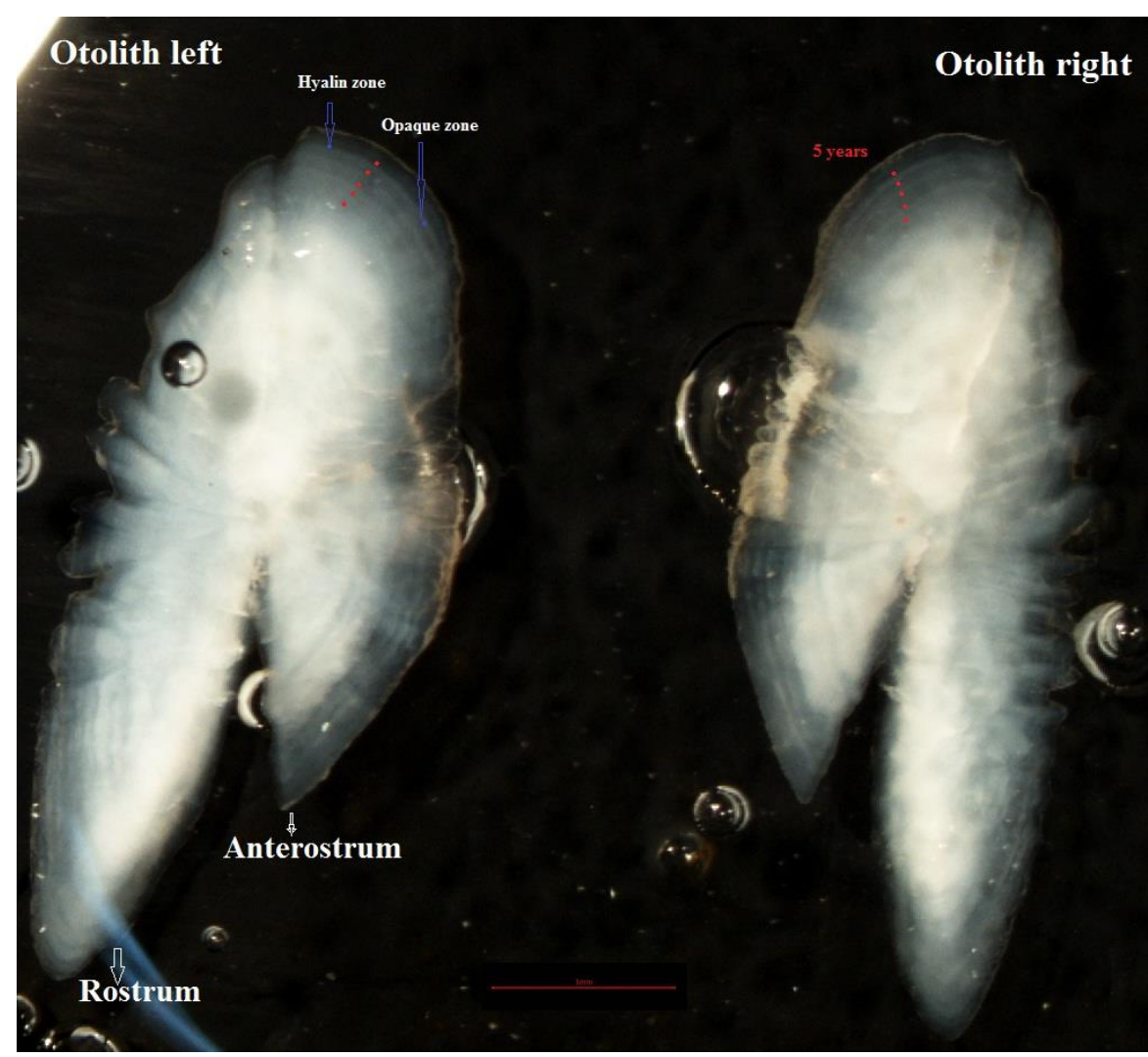

Figure 4. Otoliths (sagittae) of Sardinella aurita observed under a binocular magnifying glass in reflected light. 


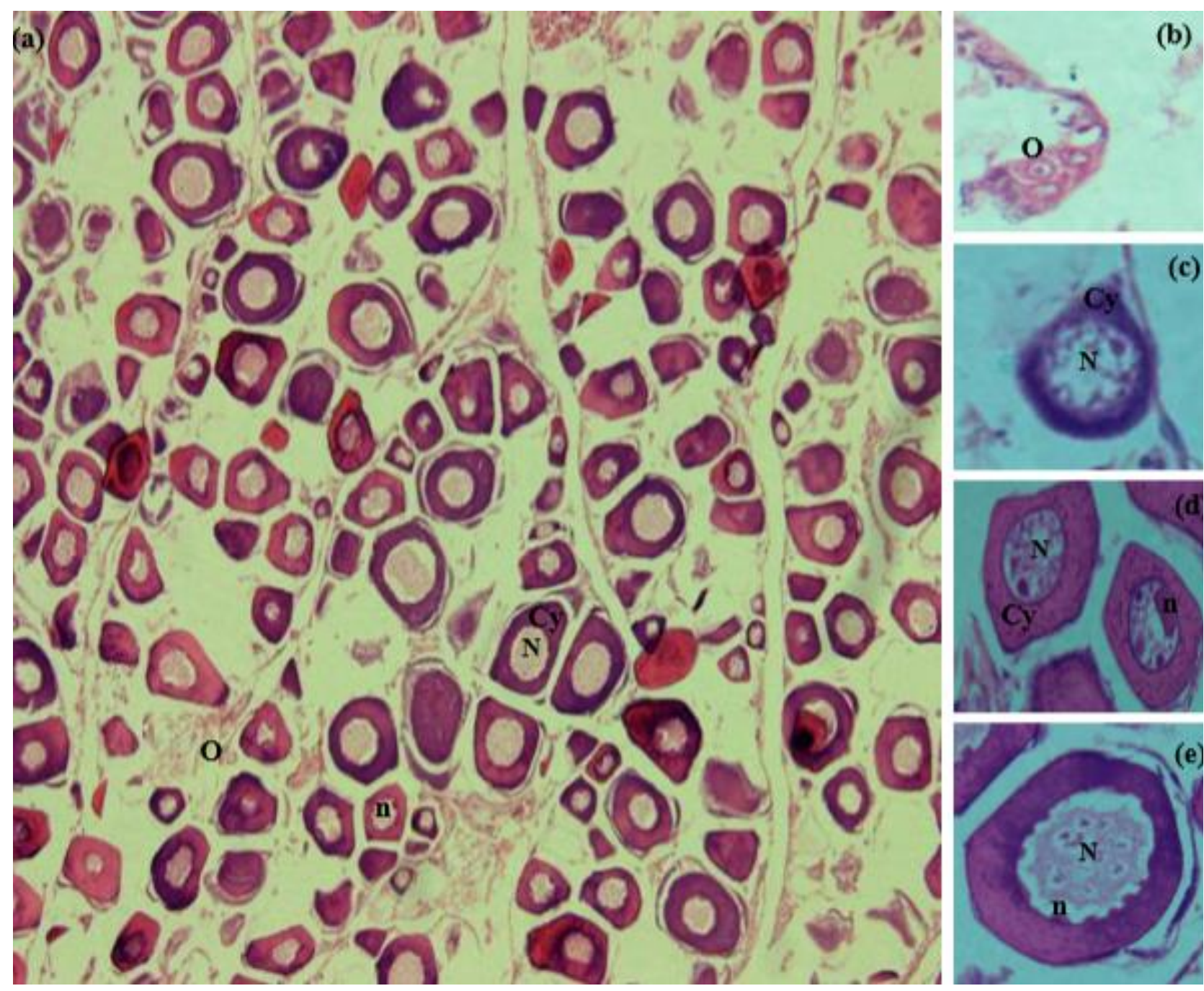

Figure 5. Histological characteristics of female gonad of $S$. aurita at the immature stage. a) cross section through an immature ovary visualizing oocytes at different stages of maturity (100x), b) Oogonia (400x), c) Nuclear chromatin stage oocyte (400x), d) and e) Early and late perinucleolar stage oocyte (400x). Cy: Cytoplasm, N: nucleus, n: nucleolus, O: oogonia.
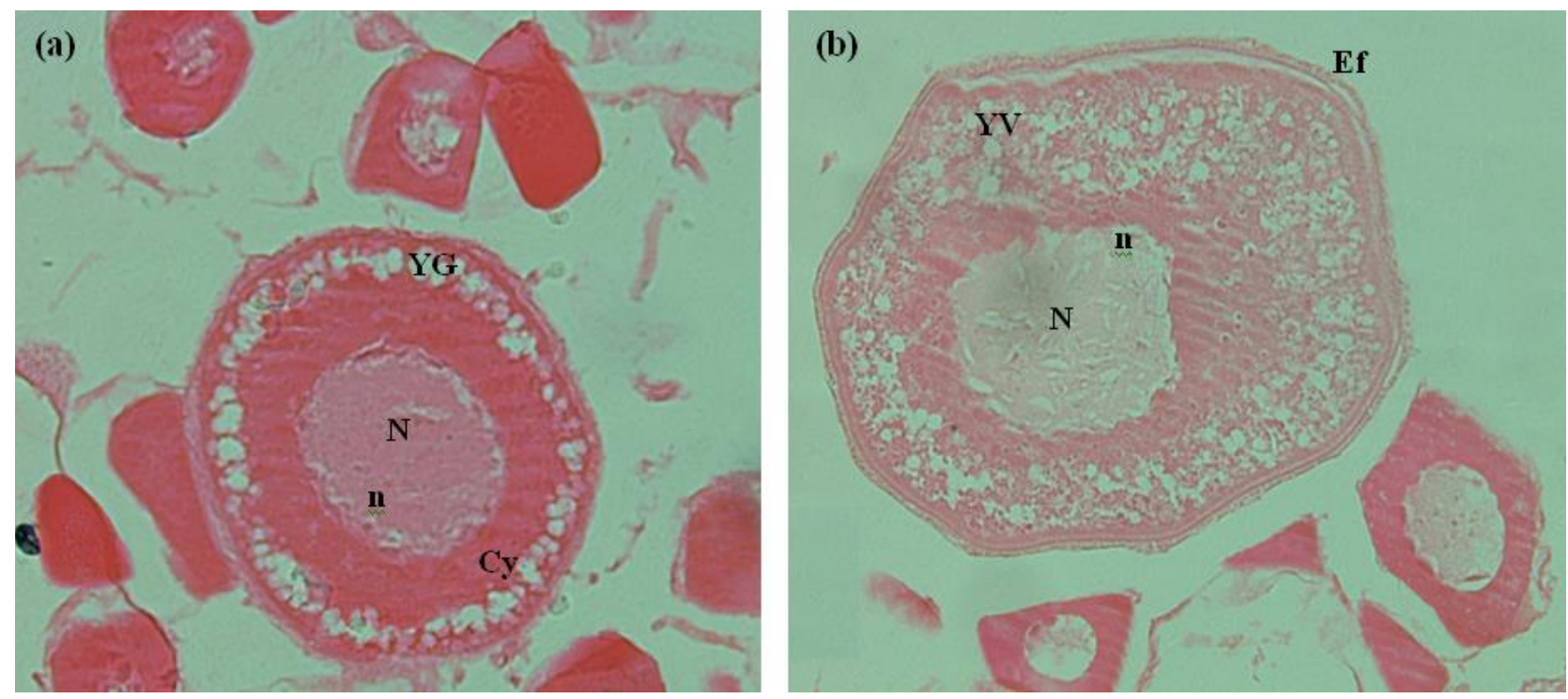

Figure 6. Histological characteristics of female gonad of S. aurita at the pre-spawning stage. a) Early development oocyte (200x), b) Late development oocyte (200x); Cy: cytoplasm, Ef: follicular envelope, N: nucleus, n: nucleolus, YG: yolk globules, YV: yolk vesicles. 
primary growth are less evident. The oocytes in advanced vitellogenesis seem to be liquefied with fused vitelline inclusions giving it a hyaline appearance with an irregular nuclear envelope. The large cytoplasm was slowly replaced with yolk platelets and the zona radiata increases in thickness. Just before laying, nucleus begins to leave central position and migrates toward periphery (Figure 7a). It is generally difficult to observe on histological sections. Ripe oocytes are detached from their follicular envelop and are released into the ovarian lumen to be expelled (Figure 7b). The appearance of follicular lights devoid of matures oocytes reveal the initiation of egg laying process (Figure 7b).

Post-spawning: Empty post-ovulatory follicles and oocytes with a loose, atretic structure characterize the ovaries at this stage (Figure 8). Also, oocytes at different stages of development are encountered but atretic oocytes are more common. Furthermore, yolk inclusions are dispersed into the lumen of the ovarian lamellae after rupture of the zona radiata of vitellogenic atretic oocytes.

Spent/Resting stage: The ovarian lamellae appeared longer and narrower, and the interstitial space between them was wider. Only some atretic oocytes and previtellogenic oocytes were discernible among the ovarian lamellae. The spaces freed by degeneration of vitellogenic oocytes are recolonized by these resting previtellogenic oocytes containing a voluminous central nucleus with numerous nucleoli (Figure 9).

\section{Fecundity}

The absolute fecundity (AF) was highly varied from 9,397 oocytes for females having $27 \mathrm{~cm}$ in TL to 176,712 oocytes for those with $33.5 \mathrm{~cm}$ in $\mathrm{TL}$, although the average absolute fecundity recorded was at 71,858 oocytes per female. As for the average of the relative fecundity, it was evaluated at 193 oocytes/g of female and ranged between 41 and 418 oocytes/g of female
(Table 3). For matured females of round sardinella, the evolution of the absolute fecundity as a function of size (TL) and total body weight (TW) showed a positive correlation estimated at 0.59 and 0.63 , respectively and an exponential relationship expressed by the following equations (Figure 10):

$$
\begin{aligned}
& F A=5 \times 10^{-8} \times T L^{8.02}\left(n=36 ; R^{2}=0.59\right) \\
& F A=0.012 \times T W^{2.64}\left(n=36 ; R^{2}=0.63\right)
\end{aligned}
$$

\section{Discussion}

\section{Growth Study}

In our study, the correlation between length and weight was high with a positive allometry, i.e. weight grows faster than length. Such results were reported from Senegal (Boëly, 1979; Camarena-Lurhs, 1986; Fréon, 1988; Diouf et al., 2010; Samba, 2011), Congo (Ghéno and Fontana, 1981), Mauritania (Holzlöhner et al., 1983; Wague and Mboji, 2002; Pascual-Alayon et al., 2008), Algeria (Bouaziz, 2007; Dahel et al., 2016) and Morocco (Baali et al., 2015) whereas Kartas (1981) and Merella et al. (1997) revealed that weight increases proportionally with length respectively in Tunis and the Balearic Islands (Spain) respectively (Table 4). It is important to note that the authors used different size ranges and units of measurement (fork length or total length, eviscerate weight), which may explain the difference between the results.

In the present study length-at-age was determined by otolith reading and Bhattacharya method. The corroboration between the two methods was satisfactory and showed that we have five age groups, which apparently agreed well with previous studies in the same area (Baali et al., 2015; Amenzoui and Baali, 2018). Growth rates of South of Moroccan Atlantic Coast specimens seem to be similar to other specimens from neighboring waters. Thus, in Mauritanian coast,
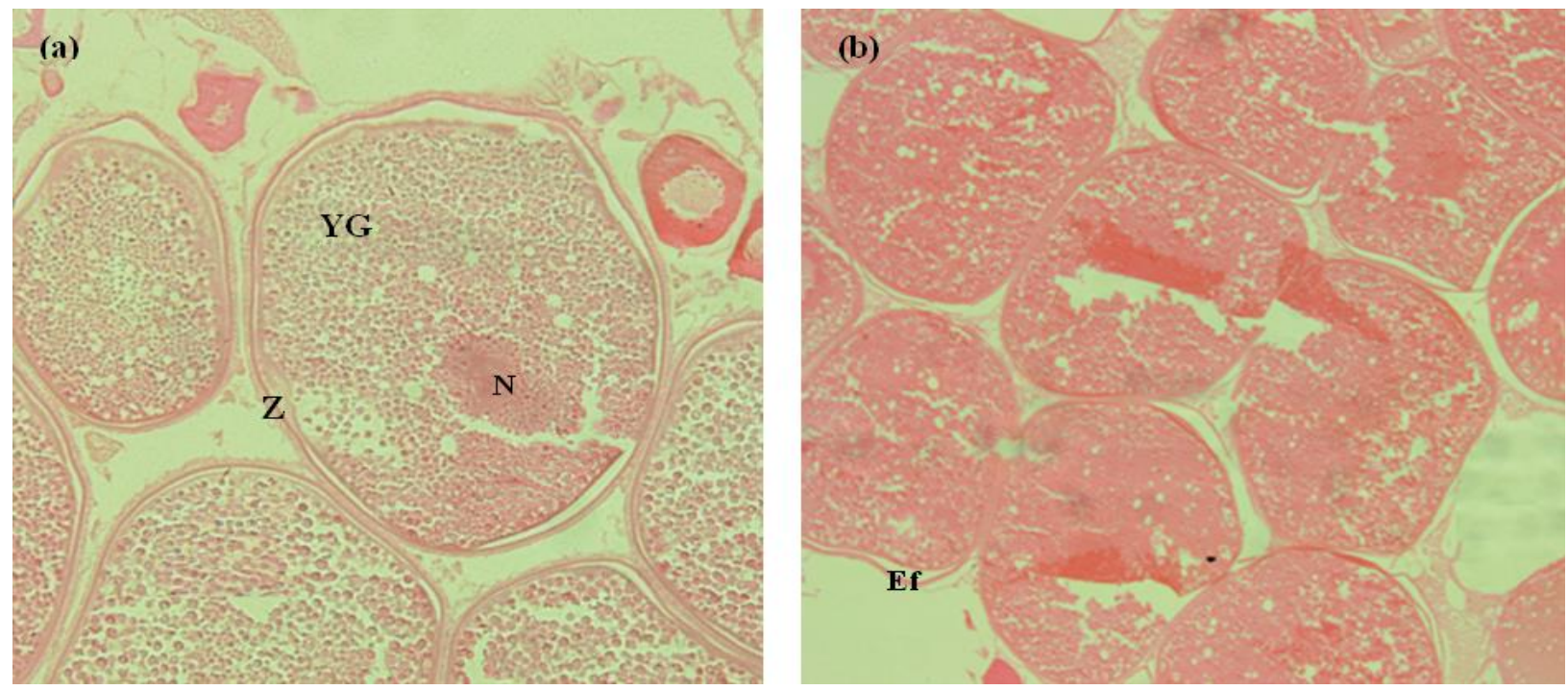

Figure 7. Histological characteristics of female gonad of S. aurita at the spawning stage. a) Nucleus Migration (100x); b) Oocytes in the spawning stage (100x); Ef: follicular envelope; YG: Yolk globules; N: nucleus; Z: zona radiata. 


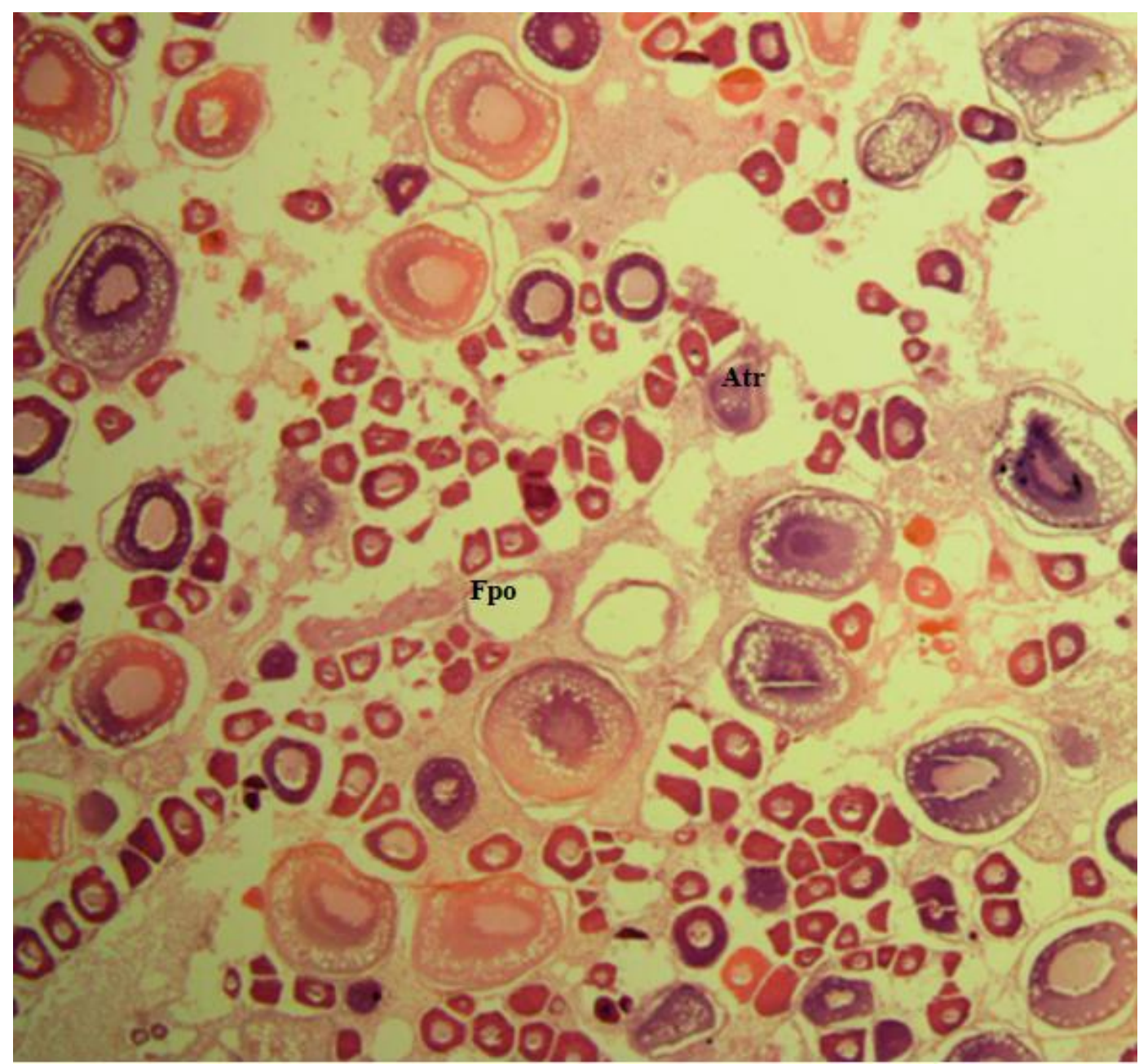

Figure 8. Histological characteristics of female gonad of S. aurita at the post-spawning stage. Atr: atretic oocytes, Fpo: postovulatory follicles (40x).

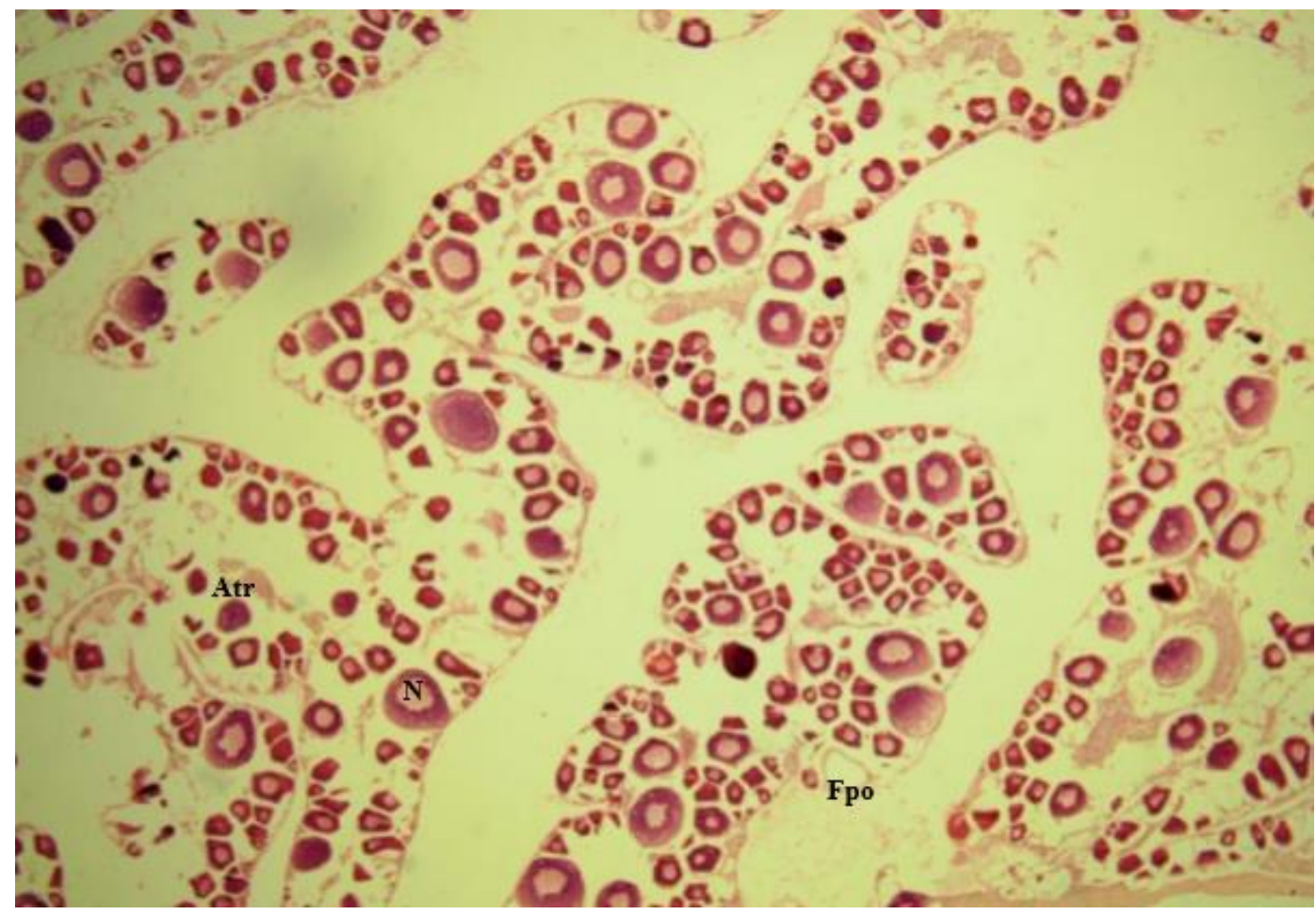

Figure 9. Histological characteristics of female gonad of $S$. aurita at the resting stage. Atr: atretic oocytes, Fpo: post-ovulatory follicles, N: nucleus (40x). 
Table 3. Estimated mean of absolute and relative fecundity for mature females of $S$. aurita.

\begin{tabular}{lcccc}
\hline & Mean & Standard deviation & Minimum & Maximum \\
\hline Absolute fecundity (oocytes) & 71858 & 42224 & 9397 & 176712 \\
Relative fecundity (oocytes/g) & 193 & 98 & 41 & 418 \\
\hline
\end{tabular}
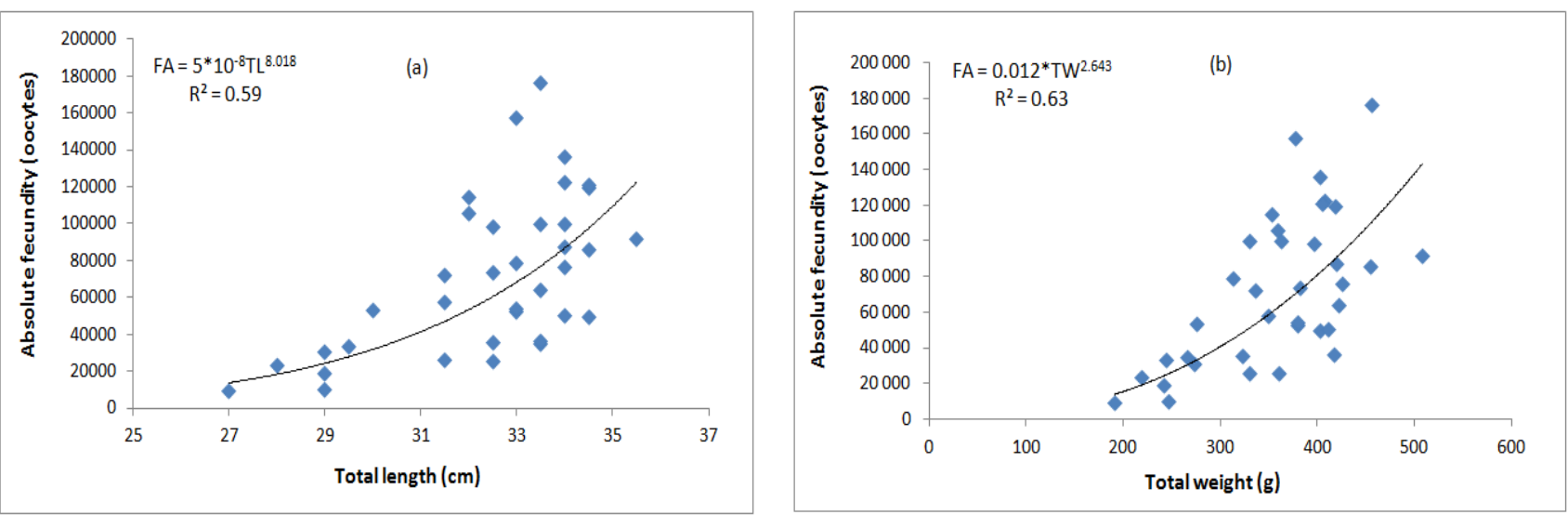

Figure 10. Absolute fecundity (FA) of round sardinella as a function of (a) total length (TL, cm) and (b) body weight (W, g).

Table 4. Length-weight relationship parameters of $S$. aurita sampled in different areas.

\begin{tabular}{lllll}
\hline Study area & \multicolumn{1}{c}{ Size range $(\mathrm{cm})$} & \multicolumn{1}{c}{$\mathrm{a}$} & \multicolumn{1}{c}{ Authors } \\
\hline Senegal & $5-32(\mathrm{FL})$ & 0.006 & 3.290 & Camarena-Luhrs (1986) \\
Senegal & - & $1.00 \mathrm{E}-06$ & 3.388 & Boëly (1979) \\
Senegal & $4-32(\mathrm{FL})$ & 0,006 & 3.274 & Fréon (1988) \\
Senegal & $7.7-40(\mathrm{TL})$ & $3.00 \mathrm{E}-05$ & 3.162 & Diouf et al. (2010) \\
Senegal & $8-36.5(\mathrm{TL})$ & $7.00 \mathrm{E}-06$ & 3.04 & Samba (2011) \\
Mauritania & $22-37(\mathrm{TL})$ & 0.002 & 3.375 & Holzlöhner et al. (1983) \\
Mauritania & $15-32(\mathrm{FL})$ & 0.008 & 3.227 & Lawal and Mylnikov (1988) \\
Mauritania & $23.6-37.5(\mathrm{TL})$ & 0.007 & 3.126 & Pascual-Alayón et al. (2008) \\
Tunisia & - & 0.007 & 3.01 & Kartas (1981) \\
Spain & - & 0.006 & 2.99 & Merella et al. (1997) \\
Algeria & - & 0.003 & 3.28 & Bouaziz (2007) \\
Algeria & $8-25.5(\mathrm{TL})$ & $0.005(\mathrm{M})$ & $3.13(\mathrm{M})$ & Dahel et al. (2016) \\
& & $0.004(\mathrm{~F})$ & $3.16(\mathrm{~F})$ & \\
Morocco & $14.5-34.5(\mathrm{TL})$ & $0.004(\mathrm{M})$ & $3.25(\mathrm{M})$ & Baali et al. (2015) \\
& & $0.004(\mathrm{~F})$ & $3.24(\mathrm{~F})$ & \\
Morocco & $12-35.5(\mathrm{TL})$ & 0.004 & 3.27 & Present work \\
\hline
\end{tabular}

Sardinella aurita are growing rapidly: $1.5 \mathrm{~cm}$ per month for the sizes ranging from 20 to $25 \mathrm{~cm}$ and $1.2 \mathrm{~cm}$ per month for sizes between 25 and $30 \mathrm{~cm}$ (Ould Sidina et al., 2006). Also, the study of Boëly (1982) in Senegal and Samba (2011) in the Cape Verde peninsula showed a very rapid growth with a maximum age observed at 4 years. Instead, a recent study conducted by Dahel et al. (2016) in the Mediterranean Sea (Algeria) showed that the round sardinella have a slow growth with a maximum age of 7 years. With regards to our study area, the values of von Bertalanffy's equation found for Sardinella aurita were not comparable with those reported in other literature (Table 5). The interpretation of the results is complex because of fish migrations and sampling method used by the authors. Indeed, we suggest that may be a problem of representativeness of one of the size classes in the samples according to the authors (a fringe of the stock may be absent or undersampled). In addition, reading otolith method tends to overestimate the $\mathrm{K}$ growth rate due to reading difficulties and the presence of false marks as indicated by Santamaria et al. (2008). Similarly, contrasts with the findings of several authors were reported for the method of reading scales (Pham-Thuoc and Szypula, 1973; Krzeptowski, 1981; Fréon, 1986; Maxim and Maxim, 1987; Chesheva, 1998). These differences can be explained by the varying of interpretation of the scales. Otherwise, whatever the method used in the present work, the L $\infty$ obtained in our study area was higher than that recorded for the Mediterranean Sea by Dahel et al. (2016) where females reach a final size $L \infty=32.26 \mathrm{~cm}$ and males $L \infty=27.3 \mathrm{~cm}$. The variability in growth may result from several factors such as difference in mortality rates, environmental conditions 
or genetic variations (Dutka-Gianelli and Murie, 2001). However, the value of growth performance $\left(\phi^{\prime}\right)$ estimated using the otolith method for age determination was similar to that of Bhattacharya's method for length frequency analysis, which supports the validity and reliability of the growth parameters calculated from both methods (Pauly, 1979). The high values obtained from this index in the Atlantic Ocean could be associated with the upwelling that takes place in the study area, while lower values could be due to low productivity waters in the Mediterranean Sea (Table 5).

\section{Histology}

Since the cellular and tissular changes in ovaries due to gametogenesis are related to the external morphochromatic features, the gonadal development phases can be identified by morphochromatic features. Nevertheless, degree of ovary's maturity, spawning's sub-phases and the difference between ovarian immature and resting phases can only be noted by the histological diagnosis. Thus, microscopic features become essential to determine with any accuracy the maturation of the gametes and confirm the macroscopic analysis.

The round sardinella is a multiple spawner that lays several times during the same breeding season. The development of oocytes takes place asynchronously, that is to say that all the oocytes do not reach maturity simultaneously. Oocytes of different stages are found throughout the reproductive period (Baali et al., 2017). The multiple breeding has been described in majority of the teleosts (Cortés and Aron, 2011).

In the present study, based on microscopic features, five stages of ovarian development were described: immature phase, mature or pre-spawning phase, spawning phase, post-spawning phase and spent phase. These same stages were found by Bouhali et al. (2015) for Sardina pilchardus from the Gulf of Annaba (Algeria), and by Chakrabarti and Barun (2017) for Gudusia chapra. The study of sardinella conducted by Fontana (1969) in the Pointe Noire region (Congo) showed the existence of six sexual stages. These same stages have been found in Sardina pilchardus (Pinto and Andreu, 1957; Amenzoui, 2010; Bedairia et al., 2016) while in Sardinella brasiliensis, seven maturity stages are established (Isaac-Nahum et al., 1983). Although the number of maturity stages differs between authors, the general pattern of oocyte development was similar in all Sardinella species. This was also reported by Le Duff (1997) in other teleost fish (Solea vulgaris, Scomber scombrus, Trachurus trachurus).

Histological comparisons between immature and resting stages revealed striking morphological resemblances such as diffused chromatin and small cytoplasm, with oocytes of stage I and II. Thus, in order to differentiate between the two stages, size at first maturity was used to identify fish in the first breeding season and fish in the resting stage after spawning period.

\section{Fecundity}

Despite the fact that round sardinella is a highly fertile species but its fecundity varies through time even if in similar environmental conditions; besides, it is dependent on the weight and size of individuals (Fontana and Pianet, 1973; Conand, 1977). The absolute fecundity (AF) of $S$. aurita showed a close interrelationship with size and weight of fish, which has been reported by other authors (Figuera, 1967; Reyes, 1981; Ramírez and Huq, 1986; Guzmán et al., 1999;

Table 5. Parameters of von Bertalanffy's equation of $S$. aurita from different areas.

\begin{tabular}{|c|c|c|c|c|c|c|}
\hline Study area & Authors & Methods & $\begin{array}{c}\mathrm{L}_{\infty} \\
(\mathrm{TL}, \mathrm{cm})\end{array}$ & $\mathrm{t}_{0}(\mathrm{an})$ & $\mathrm{k}\left(a n^{-1}\right)$ & $\phi^{\prime}$ \\
\hline Mauritania & Pham-Thuoc and Szypula, (1973) & Scales & 40.70 & 0.33 & -0.63 & 2.73 \\
\hline Mauritania & Chesheva (1998) & Scales & 41.63 & 0.26 & -0.87 & 2.66 \\
\hline Mauritania & Pascual-Alayón et al. (2008) & Otoliths & 36.6 & 0.39 & 1.46 & 2.72 \\
\hline Mauritania & Santamaria et al. (2008) & Scales and otoliths & 38.97 & 0.32 & -1.78 & 2.69 \\
\hline Senegal and Mauritania & Maxim and Maxim, 1987 & Scales & 45.22 & 0.36 & -0.69 & 2.72 \\
\hline Senegal & Boëly (1979) & Length frequency and scales & 36.92 & 0.97 & 0.21 & 2.97 \\
\hline \multirow[t]{3}{*}{ Senegal } & Krzeptowski (1981) & Scales & 43 & 0.3 & -0.95 & 2.75 \\
\hline & & & 40.69 & 0.27 & -0.99 & 2.66 \\
\hline & & & 42.12 & 0.28 & -0.99 & 2.7 \\
\hline Senegal & Boëly et al. (1982) & Length frequency and scales & 36.2 & 1.21 & -0.06 & 3.05 \\
\hline Senegal & Camarena-Luhrus (1986) & Scales & 37.77 & 0.61 & -0.75 & 2.94 \\
\hline Senegal & Fréon (1986) & Scales & 36.2 & 1.21 & -0.06 & 3.03 \\
\hline Senegal & Samba (2011) & Otoliths & 31.45 & 1.79 & 0.55 & 3.6 \\
\hline \multirow[t]{2}{*}{ Algeria } & Dahel et al. (2016) & Otoliths & 32.26 & -1.99 & 0.13 & 2.13 \\
\hline & & & 27.3 & -1.9 & 0.18 & 2.12 \\
\hline \multirow[t]{2}{*}{ Morocco } & Baali et al. (2015) & Otoliths & 33.72 & -0.34 & 0.83 & 2.97 \\
\hline & & & 33.66 & -0.02 & 0.97 & 3.04 \\
\hline \multirow[t]{2}{*}{ Morocco } & Present study & Otoliths & 34.74 & -1.03 & 0.42 & 2.74 \\
\hline & & Length frequency & 36.24 & -0.38 & 0.42 & 2.70 \\
\hline
\end{tabular}


Tsikliras and Antonopoulou, 2006). While a positive correlation has only been reported between AF and length for round sardinella populations in the Mediterranean (Bensahla Talet et al., 1988; Gaamour et al., 2001) and the eastern Atlantic (Pham-Thuoc and Szypula, 1973). Our data analysis showed that the mean relative fecundity was at $193 \pm 98$ oocytes/g , which was low compared to those obtained by Samba (2011) in the Senegalese zone (644 oocytes/g), Conand (1977) and FAO (1979) in the same area (Senegal) (400 oocytes/g), Ramírez and Huq (1986) (222 oocytes/g) in the Gulf of Cariaco, Tsikliras and Antonopoulou (2006) (462 oocytes/g) in the north-eastern Mediterranean Sea, Bensahla Talet et al. (1988) (246-933 oocytes/g) in Algerian waters and Gaamour et al. (2001) (240-480 oocytes/g) in Tunisian coast. This high variability of results could be due to either genetic differences among the round sardinella populations, or environmental conditions or a combination of both (Stearns, 1992; Wootton, 1998).

\section{Conclusion}

The data on age of Sardinella aurita (round sardinella) produced by this study suggest that age can be identified by the length frequency analysis (LFA) even if the age determination is possible from otoliths. Thus, the LFA method gives possibility to define ages only with measurement, this being beneficial since it is quick, feasible to use and less hard, especially if we overcome its disadvantages such as sampling bias (a small number of younger and/or older fish), gear and site selectivity, that makes modal separation difficult (Gallucci et al., 1996). However, the direct reading of otoliths remains the most precise method, because it gives more reliable results in years instead of age group. In addition, the current study contributes to better understand the ovarian changes of Sardinella aurita by histological diagnosis. This information also helps in understanding the histology cell pattern of the round sardinella reproduction in Moroccan waters.

\section{Ethical Statements}

The care and use of experimental animals, sampling and analysis techniques used in this work are consistent with the Moroccan Legislation Article 14, Section 3, Bill 122.22 and the Cartagena Protocol on Biosafety to the Convention on Biological Diversity promulgated by the royal decree "1.09.123".

\section{Funding Information}

This work was supported by the National Institute of Fisheries Research "INRH", which is a public organization endowed of the moral personality and financial autonomy and is a national organism, under its activities to manage fisheries resources and marine environment.

\section{Authors Contributions}

All authors are responsible for the general design of the manuscript. $A B$ conducted the research and the collect of sample and wrote the first draft of the manuscript. OB wrote the first draft of the manuscript and conducted the histological study. KCO wrote the first draft of the manuscript and conducted statistical analyses. KA and AY conduct and supervise the research project. All authors contributed on specific aspects.

\section{Conflict of Interest}

The authors declare that they have no known competing financial interests or personal relationships that could have appeared to influence the work reported on the paper.

\section{Acknowledgements}

We are grateful to Mr. Baibat, Mr. Elorch and Mrs. Boumzrague for providing part of the sample. We thank Dr. Amina T. Dahel for her help in FISAT II software for age determination. We would like to thank the reviewers for the evaluation of the manuscript and useful comments.

\section{References}

Amenzoui, K. (2010). Variabilité des Caractéristiques Biologiques de la Sardine, Sardina pilchardus (Walbaum, 1792) Exploitée au Niveau des Zones de Safi, Agadir et Laâyoune (Côtes Atlantiques Marocaines) (PhD Thesis). Mohamed V University, Rabat, Morocco.

Amenzoui, K. \& Baali, A. (2018). Biological parameters of Sardinella aurita (Valenciennes, 1847) exploited in the Dakhla zone (South Atlantic Morocco). International Journal of Scientific \& Engineering Research, 9(8), 85-90.

Arneri, E., Colella, S. \& Giannetti, G. (2001). Age determination and growth of turbot and brill in the Adriatic Sea: reversal of the seasonal pattern of otolith zone formation. Journal of Applied Ichthyology, 17, 256-261.

Baali, A., Yahyaoui, A., Amenzoui, K., Manchih, K., \& Abderrazik, W. (2015). A preliminary study of reproduction, age and growth of Sardinella aurita (Valenciennes, 1847) in the southern of Atlantic Moroccan area. Aquaculture, Aquarium, Conservation \& Legislation - International Journal of the Bioflux, 8(6), 960-974.

Baali, A., Bourassi, H., Falah, S., Abderrazik, W., Manchih, K., Amenzoui, K., \& Yahyaoui, A. (2017). Reproductive Biology of Sardinella sp. (Sardinella aurita and Sardinella maderensis) in the South of Morocco. Pakistan Journal of Biological Sciences, 20, 165-178. http://dx.doi.org/10.3923/pjbs.2017.165.178

Baali, A., Charouki, N., Manchih, K., Bessa, I., Elqoraychy, I., Elqendouci, M. \& Yahyaoui, A. (2019). The relationship between Sardinella aurita landings and the environmental factors in Moroccan waters $\left(21^{\circ}-26^{\circ} \mathrm{N}\right)$. Cybium, 43(1), 51-59.

http://dx.doi.org/10.26028/cybium/2019-431-005.

Bagenal, T.B., \& Braum, E. (1978). Eggs and early life history. In 
T.B. Bagenal (eds.), Methods for Assessment of Fish Production in Freshwaters (pp. 165-201). Oxford, England, IBP Handbook 3, Blackwell Scientific, Oxford.

Bakun, A., \& Parrish, R.H. (1990). Comparative studies of coastal pelagic fish reproductive habitats: the Brazilian sardine (Sardinella aurita). ICES Journal of Marine Science., 46(3), 269-283.

https://doi.org/10.1093/icesjms/46.3.269

Bard, F.X., \& Koranteng, K.A. (1995). Dynamics and Use of Sardinella Resources from Upwelling of Ghana and Ivory Coast. In Accra (Paris: Office de la recherche scientifique et technique outre-mer Eds), Proceedings of Scientific Meeting. Accra, Ghana, 438 pp.

Bedairia, A., Djebar, A.B., \& Jarray, M. 2016. Histological Characteristic of the Gonads of Sardine Sardina Pilchardus (Walb, 1792) in the Coast East of Algeria (Gulf of Annaba). American International Journal of Biology, 4(2), 23-37.

Bensahla-Talet, A., Mortet, Y., \& Tomasini, J.A. 1988. Relations masse-longueur, sex-ratio et reproduction (saison de ponte, fécondités) de Sardinella aurita (Val. 1847) des cotes Oranaises (Algérie). Commission internationale pour l'exploration scientifique de la mer Méditerranée 31 (Report No V-II : 14).

Beverton, R.J.H., \& Holt, S.J. 1957. On the dynamics of exploited fish populations. Fisheries Investigations, 19, 1-533.

Boëly, T. (1979). Biologie de deux espèces de sardinelles (Sardinella aurita, Valenciennes, 1847 et Sardinella maderensis, Lowe, 1841) des côtes Sénégalaises (PhD Thesis). Pierre et Marie Curie-Paris VI University. Paris, France.

Boëly, T., Chabanne, J., Fréon, P., \& Stequert, B. (1982). Cycle sexuel et migrations de $S$. aurita sur le plateau continental ouest-africain des iles Bissagos a la Mauritanie. International Council for the Exploration of the Sea (Report and minutes No. 180), 350-355pp.

Bouaziz, A. (2007). La sardinelle (Sardinella aurita Valenciennes, 1847) des côtes algériennes : distribution, biologie et estimation des biomasses (PhD Thesis). des Sciences et de la Technologie Houari Boumediene University, Alger, Alegria.

Bouaziz, A., Bennoui, A., Brahmi, B., \& Semroud, R. (2001). Sur l'estimation de l'état d'exploitation de la sardinelle (Sardinella aurita Valenciennes, 1847) de la région centre de la côte algérienne. Metting Commission internationale pour l'exploration scientifique de la mer Méditerranée (Report and minutes No 36.). 244pp.

Bouhali, F.Z., Lechekhab, S., Ladaimia, S., Bedairia, A., Amara, R. \& Borhane, A.D. (2015). Reproduction et maturation des gonades de Sardina pilchardus dans le golfe d"Annaba (Nord-Est algérien). Cybium, 39 (2), 143-153.

Camarena-Luhrs, T. (1986). La croissance de Sardinella maderensis (Lowe, 1841) au Sénégal. Océanographie tropicale, 21 (2), 143-151.

Chakrabarti, P., \& Barun, S. (2017). Histological organization and surface ultrastructure of ovaries of Gudusia chapra during different phases of reproduction (Teleostei: Clupeidae). Iranian Journal of Ichthyology, 4 (1), 41-53.

Chesheva, Z.A. (1998). The method for determining age and growth rate of gilt sardines Sardinella aurita in the Senegal-Mauritania population. Journal of Ichthyology, 38(9), 814-817.

Conand, C. (1977). Contribution à l'étude du cycle sexuel et de la fécondité de la sardinelle ronde, Sardinella aurita: pêche sardinière dakaroise en 1975 et premier semestre 1976. Cahiers Office de la recherche scientifique et technique outre-mer Série Océanographie, 15 (4), 301312.

Cortés, N., \& Aron, A. (2011). Reproductive cycle and batch fecundity of Isacia conceptionis (Perciformes, Haemulidae) at La Herradura, Coquimbo, Chile. Revista de Biología Marina y Oceanografía, 46, 101-104. http://dx.doi.org/10.4067/S0718-19572011000100016.

Cury, P., \& Fontana, A. (1988). Compétition et stratégies démographiques comparées de deux espèces de sardinelles (Sardinella aurita et Sardinella maderensis) des côtes ouest africaines. Aquatic Living Resources, 1, $165-180$

Dahel, A., Tahri, M., Bensouilah, M., Amara, R., \& Djebar, B. (2016). Growth, age and reproduction of Sardinella aurita (Valenciennes, 1847) and Sardina pilchardus (Walbaum, 1792) in the Algerian eastern coasts. Aquaculture, Aquarium, Conservation \& Legislation International Journal of the Bioflux, 9 (5), 1172-1181.

Diouf, K., Samb, B., \& Sylla, M. (2010). Contribution à la connaissance de la biologie des sardinelles (Sardinella aurita et Sardinella maderensis) du littoral sénégalais. In S. Garcia, M. Tandstad, \& A.M. Caramelo (Eds.). Science and Management of Small Pelagics Symposium on Science and the Challenge of Managing Small Pelagic Fisheries on Shared Stocks in Northwest Africa (pp.3956). Casablanca, Morocco, FAO Fisheries and Aquaculture Proceedings No. 18. Rome, FAO, 431 pp.

Durand, M-H., Cury, P., Mendelssohn, R., Roy, C., Bakun A., \& Pauly, D. (1998). Global versus Local Changes in Upwelling Systems. Paris, France, Office de la recherche scientifique et technique outre-mer Press, 608pp.

Dutka-Gianelli, J., \& Murie, DJ. (2001). Age and growth of sheephead, Archosargus probatocephalus (pisces: Sparidae), from the northwest coast of Florida. Bull of Marine Science, 68(1), 69-83.

El-Haweet, A., Hegazy, M., Abuhatab, H., \& Sabry, E. (2005). Validation of length frequency analysis for Boops boops (bogue) growth estimation. Egyptian Journal Of Aquatic Research, 31(1), 399-408.

FAO. (1979). Rapport du groupe de travail Ad Hoc sur les poissons pélagiques côtiers ouest-africains de la Mauritanie au Libéria $\left(26^{\circ} \mathrm{N}\right.$ à $\left.5^{\circ} \mathrm{N}\right)$. Retrieved from http://www.fao.org/3/N0952F/N0952F00.htm

Farley, J.H., Davis, T.L.O., Bravington, MV., Andamari, R., \& Davies, C.R. (2015). Spawning Dynamics and Size Related Trends in Reproductive Parameters of Southern Bluefin Tuna, Thunnus maccoyii. PLoS One, 10(5), e0125744. doi: 10.1371/journal.pone.0125744

Figuera, F. (1967). Contribución a los conocimientos de la fecundidad en la Sardinella sp. del Golfo de Cariaco (PhD Thesis). Universidad de Oriente, Cumaná, Sucre, Venezuela.

Fontana, A. (1969). Etude de la maturité sexuelle des sardinelles Sardinella eba (Val.) et Sardinella aurita (C et V) de la région de Pointe-Noire. Cahier Office de la recherche scientifique et technique outre-mer, séries Océanographie, 7, 101-114.

Fontana, A., \& Pianet, R. (1973). Biologie des sardinelles, Sardinella eba (Val.) et Sardinella aurita (Val.) des côtes du Congo et du Gabon. Paris, France, Office de la recherche scientifique et technique outre-mer (Nouvelle Série $\mathrm{N}^{\circ} 31$ ), $40 \mathrm{pp}$. 
Fréon, P. (1988). Réponses et adaptations des stocks de Clupéidés d'Afrique de l'Ouest à la variabilité du milieu et de l'exploitation. Paris, France, Office de la recherche scientifique et technique outre-mer (Etudes et Thèses), $287 \mathrm{pp}$.

Fréon, P., El Khattabi, M., Mendoza, J., \& Guzman, R. (1997). Unexpected reproductive strategy of Sardinella aurita off the coast of Venezuela. Marine Biology, 128, 363372.

Froese, R. (2006) Cube law, condition factor and weight-length relationships: history, meta-analysis and recommendations. Journal of Applied Ichthyology, 22, 241-253.

Gaamour, A., Missaoui, H., Ben-Abdallah, L. El Ahmed, A. (2001). Paramètres biologiques de la sardinelle ronde (Sardinella aurita Valenciennes, 1847) dans la région du cap Bon (canal siculotunisien). Retrieved from www.faocopemed.org/en/sac/docs.htm

Gallucci, V.F., Saila, S. B., Gustafson, D.J., \& Rothschild, B.J. (1996). Stock Assessment, Quantitative Methods and Applications for Small-Scale Fisheries, Boca Raton, Florida, USA, CRC Press.

Gayanilo, F.C.Jr., Sparre, P., Pauly, D. (2005). FAO-ICLARM Stock Assessment Tools II (FiSAT II). Revised version. User's guide. FAO Computerized Information Series (Fisheries). No.8, Revised version. Rome, Italy, FAO., 168 $\mathrm{pp}$.

Ghéno, Y., \& Fontana, A. (1981). Les stocks de petits pélagiques côtiers les sardinelles. In A. Fontana (Eds), Milieu marin et ressources halieutiques de la république populaire du Congo (pp. 213-257). Paris, France, Document Office de la recherche scientifique et technique outre-mer $\mathrm{N}^{\circ} 138$., 339pp.

Guzmán, R., Gómez G., \& Penott M. (1998). Aspectos biológicos y pesquería de la sardina (Sardinella aurita) en Golfo de Cariaco, Venezuela. Zootecnia Tropical, 16(2), 149- 162.

Holden, M.J., \& Raitt, D.F.S. (1974). Manuel des sciences halieutiques. Deuxième partie. Méthodes et recherches sur les ressources et leur application. Rome, Italy, FAO, Document Technique sur les Pêches, (115), Rev. 1., 223 $\mathrm{pp}$.

Holzlöhner, S., Kloxin, C., Pingel, C., \& Hoffmann, U. (1983). On the species composition and length-age structure of the most important pelagic fishes off Mauritania in 1982. International Council for the Exploration of the Sea, Pelagic Fish Committee., 44pp.

Isaac-Nahum, V.J., Vazzoler, A. E. A. De M. and Zanetti-Prad0 E. M. (1983) Estudos sobre estrutura, ciclo de vida e comportamento de Sardinella brasiliensis (Steindachner, 1879), na area entre $22^{\circ} \mathrm{S}$ e $28^{\circ} \mathrm{S}$, Brasil, 3 , Morfologia e histologia de ovarios e escala de maturidade. Boletim do Instituto Oceanográfico, 32 (1), 1-16. http://dx.doi.org/10.1590/S0373-55241983000100001

Kartas, F. (1981). Les clupéidés de Tunisie. Caractéristiques biométriques et biologiques. Étude comparée des populations de I'Atlantique est et de la Méditerranée (PhD Thesis). Tunis University, Tunis, Tunisia.

Krzeptowski, M. (1981). Growth characteristics of gilt sardine (Sardinella aurita Val., 1847) from Senegal. Acta Ichthyologica et Piscatoria, 11(2), 27-38.

Lawal, H.S., Mylnikov, N. (1988). Contribution à l'étude de la relation taille-poids de la reproduction et du sex-ratio des principales espèces pélagiques en Mauritanie. Groupe de travail CNROP/CRODT/ISRA sur les ressources pélagiques côtières (Mauritanie-Sénégal) (Report). Nouadhibou, Mauritania,. 82-97 pp.

Le Duff, M. (1997). Cinétique de l'ovogenèse et stratégies de ponte chez les poissons téléostéens en milieu tempéré (PhD Thesis). Bretagne Occidentale university. Bretagne, France.

Merella, P., Quetglas, A., Alemany, F., \& Carbonell, A. (1997). Length-weight relationship of fishes and cephalopods from the Balearic Islands (western Mediterranean). Naga. International Center for Living Aquatic Resources Management Quarterly, 20(3/4), 66-68.

Martoja, R. (1967). Initiation aux techniques de I'histologie animale. Paris, France, Masson, 349 pp.

Maxim, C., \& Maxim, C. (1987). Évaluation du stock de sardinelle ronde (Sardinella aurita Valenciennes, 1847) sénégalo-mauritanienne. Cercetari marine IRDM Constata, 20/21, 313-344.

Munro, J.L., \& Pauly, D. (1983). A simple for comparing the growth of fishes and invertebrates. Fishbyte, 1(1), 5-6.

Mustać, B and Sinovčić, G. (2012). Reproductive cycle of gilt sardine, Sardinella aurita, Valenciennes 1847, in the eastern middle Adriatic Sea. Journal of Applied Ichthyology. 28, 46-50.

Nikolsky, G.V. (1963). The ecology of fishes. London, UK, Academic Press Inc., 352 pp.

Ould Sidina, E., Samb, B., \& Corten, A. (2006). Croissance de la sardinelle ronde (Sardinella aurita) dans la région nordouest africaine, estimée à partir des fréquences de tailles, a workshop from August 28 to 31 (pp. 1-14). Nouakchott, Mauritania.

Pajuelo, J.G. \& Lorenzo, J.M. (2000). Reproduction, age, growth and mortality of axillary seabream, Pagellus acarne, from the canarian archipelago. Journal of Applied Ichtyology, 16, 41-47.

Pascual-Alayón, P., Santamaría, M.T.G., \& Hernández, E. (2008). Spanish Report on the activity of European pelagic trawlers fishing in Mauritania and landing in the port of Las Palmas de Gran Canaria, Spain. Nine Meeting of the FAO Working Group on the Assessment of Small Pelagic Fish off Northwest Africa (Report). Nouakchott, Mauritania, $23 \mathrm{pp}$.

Pauly, D., (1979). Theory and management of tropical multispecies stocks: a review with emphasis on the Southeast Asia Fisheries. Manila, Philippines, International Center for Living Aquatic Resources Management (ICLARM). Rev. 1., 35pp.

Pauly, D., \& Munro, J.L. (1984). Once more on the comparison of growth in fish and invertebrates. Fishbyte, International Center for Living Aquatic Resources Management, 2(1), 1-21.

Petrakis, G., \& Stergiou, K.I. (1997). Size selectivity of diamond and square mesh codends for four commercial Mediterranean fish species. ICES Journal of Marine Science, 54(1), 13-23. https://doi.org/10.1006/jmsc.1996.0172

Pham-Thuoc., \& Szypula, J. (1973). Biological characteristics of gilt sardine Sardinella aurita Cuv. et Val. 1847 from the north-west African coast. Acta Ichthyologica et Piscatoria, 3 (1), 19-36.

Pinto, J.S., \& Andreu, B. (1957). Scale for the determination of evolutive phases of sardine (Sardina pilchardus, Walb.) ovaries in connection with the histophysiology of the gonad. Proceedings and Technical Papers from the General Fisheries Council for the Mediterranean, 46, 393411. 
Quaatey, S.N.K., \& Maravelias, C.D. (1999). Maturity and spawning pattern of Sardinella aurita in relation to water temperature and zooplankton abundance off Ghana, West Africa. Journal of Applied Ichthyology, 15, 63-69.

Ramírez, I., \& Huq, M. (1986). Aspectos reproductivos de la sardina, Sardinella aurita Valenciennes, 1847 (Pisces: Clupeidae) del Golfo de Cariaco, Estado Sucre, Venezuela. Boletim do Instituto Oceanográfico, 25, 3-20.

Reyes, D. (1981). Aspectos reproductivos de Sardinella aurita (Pisces: Clupeidae) (Bachelor's degree Thesis). Oriente University, Cumaná, Sucre, Venezuela.

Roy, C., Cury, P., Fontana, A., \& Belvèze, H. (1989). Stratégies spatio-temporelles de la reproduction des clupéidés des zones d'upwelling d'Afrique de I'Ouest. Aquatic Living Resources, 2(1), 21-29.

Santamaria, M.T.G., González, J.F., Barrera, A., López Abellán, L.J., Quintero, M.E., \& Balguerías, E. (2008). Substitution of sardine (Sardina pilchardus) for Round Sardinella (Sardinella aurita) in the Canary Islands waters. Symposium on Eastern Boundary Upwelling Ecosystems: Integrative and Comparative Approaches (pp. 2-6). Las Palmas, Gran Canaria, Spain, Progress in Oceanography., 428pp.

Samba, O. (2011). Nouvelle évaluation des caractéristiques biologiques de Sardinella aurita (Valenciennes, 1847) et
Sardinella maderensis (Lowe, 1841) (DEA Thesis). Cheikh Anta Diop de Dakar University, Dakar, Senegal.

Simpson, A.C. (1951). The spawing of the plaice (Pleuronectes platessa) in the North sea. Fish Investment, 22(2), 1-111.

Stearns, S.C. (1992). The Evolution of Life Histories. New York, USA, Oxford University Press., 262 pp.

Tsikliras, A., \& Antonopoulou, E. (2006). Reproductive biology of round sardinella (Sardinella aurita) in the northeastern Mediterranean. Scientia Marina, 70(2), 281-290.

Wassef, E., Ezzat, A., Hashem, T., \& Faltas, S. (1985). Sardine fishery by purse-seine on the Egyptian Mediterranean coast. Marine Ecology Progress Series, 26, 11-18.

Wague, A., \& Mbodj, O.B. (2002). Etude de quelques aspects de la reproduction chez la sardinelle ronde Sardinella aurita (Valencienne, 1847) péchée le long des côtes mauritaniennes. Bulletin scientifique de l'Institut Mauritanien de Recherches Océanographiques et des Pêches, 29, 13-18.

Walther, G.R., Post, E., Convey, P., Menzel, A., Parmesan, C., Beebee, T.J., Bairlein, F. (2002). Ecological responses to recent climate change. Nature, 416, 389-395. https://doi.org/10.1038/416389a

Wootton, R.J. (1998). Ecology of Teleost Fishes. Dordrecht/Boston: Kluwer Academic Publishers, Chapman \& Hall fish and fisheries series 24., 386 pp. 